\title{
Umbilical Artery Catheterization in the Newborn
}

\author{
J. M. GUPTA $\ddagger$, N. R. C. ROBERTON†‡, and J. S. WIGGLESWORTH \\ From the Nuffield Neonatal Research Unit, Institute of Child Health, Hammersmith Hospital, London
}

Satisfactory care of the sick premature newborn baby requires investigations of blood gas tensions (Dahlenburg et al., 1968) and of various biochemical parameters, such as blood sugar, often at frequent intervals during the first few hours of life. Blood samples for biochemistry can be obtained from heel pricks or by venepuncture. Heel pricks are painful, may become infected, and the number which can be carried out is limited. Repeated venepuncture in the newborn carries its own not inconsiderable hazards (McKay, 1966; Asnes and Arendar, 1966). Blood can be obtained from umbilical venous catheters, but here air embolus is a hazard, as is portal venous thrombosis, though this is rare with greater attention to sterile techniques (Tizard, 1962); unless the umbilical venous catheter passes through the ductus venosus into the inferior vena cava it tends to wedge in a branch of the portal sinus and needs periodic manipulation before blood can be withdrawn.

To obtain specimens for blood gas analyses direct arterial puncture or arterialized capillary blood can be used. To obtain blood by the latter route for accurate and repeated estimations requires considerable skill, and with the peripheral vasoconstriction often found in ill babies, the results may be inaccurate. In both cases the child is traumatized, cries, and may therefore lower his $\mathrm{P}_{\mathrm{a}} \mathrm{CO}_{2}$. A haematoma may form round an arterial puncture and equilibrate with a high oxygen tension present in the skin if the child is being nursed in a high oxygen concentration, and give a falsely high $\mathrm{P}_{\mathrm{a}} \mathrm{O}_{2}$ if it is aspirated. This especially applies to temporal artery puncture. It is again not practicable to obtain repeated samples by these routes. For these reasons sampling of arterial blood through an umbilical artery catheter is preferable for both biochemical and blood gas determinations.

Before arterial catheterization could be considered

Received November 16, 1967.

* Present address: Department of Paediatrics, University of Khartoum.

$\dagger$ Requests for reprints should be addressed to N.R.C.R.

$\ddagger$ Percy J. Neate Research Fellows of the Clothworkers Company. the sterility of the cord stump had to be investigated. We report the results of the initial study of methods for maintaining cord sterility, and then the technique of arterial catheterization and the complications encountered in the years 1963-66.

\section{Material and Methods}

To investigate umbilical stump sterility a pilot study was carried out in normal babies. At birth and daily thereafter hexachlorophene soap was applied to the umbilical cord of all babies. Alternate babies had their cords sprayed with neomycin, polymyxin, and bacitracin powder (Polybactrin) at birth and daily thereafter. Swabs for culture were taken routinely immediately before the daily application of Polybactrin and/or hexachlorophene, for the first 5 days of life.

Table I shows a significant improvement in the cord sterility using Polybactrin. Table II shows the organisms cultured. Of the 5 positive cultures in the

TABLE I

Effect of Phisohex and Phisohex+Polybactrin on Umbilical Swab Cultures

\begin{tabular}{c|c|c|c}
\hline Cleanser & $\begin{array}{c}\text { No. of } \\
\text { Babies }\end{array}$ & No. of Swabs & $\begin{array}{c}\text { No. with } \\
\text { Positive } \\
\text { Cultures }\end{array}$ \\
\hline $\begin{array}{l}\text { Hexachlorophene a } \\
\begin{array}{c}\text { Hexachlorophene and } \\
\text { Polybactrin .. }\end{array}\end{array}$ & 11 & 55 & 22 \\
\hline
\end{tabular}

$\chi^{2}=9.98 ; 0.01>p>0.001$ for one degree of freedom.

TABLE II

Organisms Cultured from Positive Umbilical Swabs

\begin{tabular}{|c|c|c|}
\hline \multirow[b]{2}{*}{ Organism } & \multicolumn{2}{|c|}{ Cleanser } \\
\hline & Hexachlorophene & $\begin{array}{c}\text { Hexachlorophene } \\
\text { and } \\
\text { Polybactrin }\end{array}$ \\
\hline $\begin{array}{l}\text { Mixed growth . } \\
\text { Staphylococcus albus } \\
\text { Micrococci } \\
\text { Coliforms } \quad . . \\
\text { Streptococcus } \\
\text { faecalis }\end{array}$ & $\begin{array}{r}1 \\
3 \\
3 \\
15 \\
-\end{array}$ & $\begin{array}{l}\overline{2} \\
\overline{2} \\
1\end{array}$ \\
\hline
\end{tabular}


Polybactrin sprayed group, 2 were positive in the first 2 days of life in the same baby, and it was subsequently found that this child had not been sprayed with Polybactrin immediately after birth. The later swabs were negative. This policy of routine spraying of the cords has not only prevented local infection but has also eliminated staphylococcal infection as a hazard in our newborn babies. As the cord stump remains dry and sterile it takes much longer (up to 3 weeks) to separate by dry instead of wet gangrene.

\section{Technique}

The technique used for inserting umbilical artery catheters is simple. It is usually possible to insert the catheter for the first time up to 48-72 hours of age, though they have been passed for the first time at 10 days. Only if the umbilical cord stump is sterile (and therefore clean) are the umbilical artery orifices easily identifiable after 72 hours. The size of the baby is not critical; catheters have been passed in babies under $400 \mathrm{~g}$. and for the first time at 7 days in a $920 \mathrm{~g}$. baby.

The catheterization is carried out with full sterile precautions within the incubator. Babies requiring more than $40 \% \mathrm{O}_{2}$ are better placed in a Gairdner (Warley and Gairdner, 1962) box at this stage, as it is difficult to maintain the oxygen concentration within the incubator higher than this with the portholes open. The cord stump and surrounding skin are cleaned with a $2.5 \%$ solution of iodine in spirit. It is important to ensure that all the iodine is cleaned off to prevent iodine burns, particularly in the very immature baby.

The cord is cut $0 \cdot 5-1 \cdot 0 \mathrm{~cm}$. from the skin-umbilical cord junction, and the vessels are usually obvious on the cut surface. The umbilical arteries may still be patent in the first few hours of life and it is wise to tie a cord ligature loosely round the base of the cord to prevent a brisk arterial haemorrhage and a slow ooze from the umbilical vein. The orifice of the artery is then teased open with a special dilator (Fig. 1). Great care should be taken at this stage as it is very easy to make a false passage in the adventitia of the artery or in the jelly around it, a mistake that is difficult to correct. A K32 FG 5 polyvinyl feeding tube of outside diameter $2 \mathrm{~mm}$. (Pharmaseal Inc.) is then inserted. The catheter lumen is previously filled with normal saline containing $10 \mathrm{u}$. heparin $/ \mathrm{ml}$. The syringe containing heparinized saline is attached to the open end of the catheter. Once within the artery orifice the catheter can usually be slid gently in. Obstruction may occur
TABLE III

Distances at Which Catheters Must be Inserted to Reach Diaphragm

\begin{tabular}{c|c}
\hline Body Weight (g.) & Distance (cm.) \\
\hline 1000 & $8-10$ \\
$1000-1500$ & $10-11$ \\
$1500-2000$ & $11-12$ \\
$2000-2500$ & $12-13$ \\
2500 & $14-15$ \\
\hline
\end{tabular}

at a distance of 1-2 cm. where the vessels turn suddenly downwards. This can usually be overcome by pulling the stump upwards towards the baby's head. It is easy at this stage to create a false passage by forcing the catheter through the arterial wall. A second site of obstruction is at a distance of 5-6 cm., due presumably to spasm and kinking of the artery at its origin from the iliac vessels. Gentle sustained pressure with the catheter will usually result in the obstruction being passed. At a distance of $6-10 \mathrm{~cm}$. blood can easily be withdrawn. It is aimed to push the catheter to the level of the diaphragm. Table III shows the average distance the catheter has to be pushed in to reach this site in babies of various sizes.

The catheter is held in place by a purse-string suture of chromic catgut around the umbilical cord and a double spiral arrangement tied tightly around it. It is subsequently kept patent, by keeping it full of heparinized saline $(10 \mathrm{u} . / \mathrm{ml}$.). The catheter volume is $0.2 \mathrm{ml}$., and every time a sample is withdrawn the catheter is flushed through with $0.3 \mathrm{ml}$. heparinized saline, and a bung is inserted in the end held firmly in place with adhesive tape. It is not necessary to keep a constant infusion going, nor is it necessary to flush the catheter through at set intervals; this will only result in overheparinizing the baby.

In most cases where we insert arterial catheters we insert an umbilical venous catheter, which is of particular value for giving alkali in the respiratory distress syndrome (RDS) (Gupta, Dahlenburg, and Davis, 1967). It is usually easier to insert the arterial catheter first, unless the slow ooze from the vein is troublesome as the venous catheter hinders manipulation at the umbilicus.

In all cases once the catheters are sutured in place, Polybactrin spray is applied and the stump covered with a sterile dressing. Thereafter the cord is sprayed daily with Polybactrin until the catheter is removed. It is

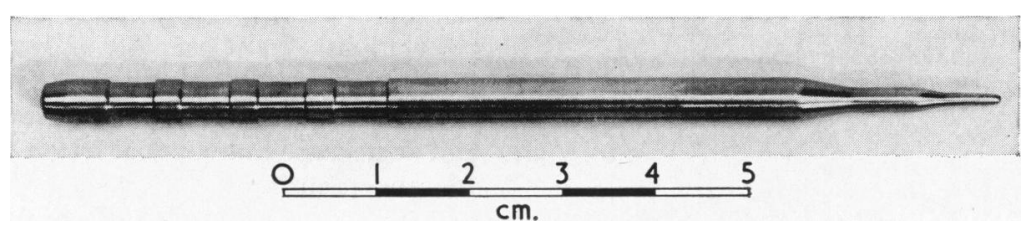

Fig. 1.-Umbilical artery dilator (designed by Professor L. B. Strang). 
important to have the catheters easily identified lest the arterial one be confused with the venous one and vice versa. If there is any doubt about the localization of the catheter either a pressure tracing or a plain $x$-ray can be taken.

To remove the catheter the hard dried scab of Wharton's jelly is cut away down to fresh tissue. A new purse-string suture is then inserted around the stump and the catheters gently withdrawn. It is important to have the purse-string in situ in freshened tissue before the catheters are withdrawn, otherwise, on pulling it tight, the arterial lumen will not be occluded and a brisk haemorrhage will result. The catheters are usually necessary for the first 24-48 hours after insertion in RDS or in babies needing metabolic monitoring. However, if the clinical state of the baby warrants it, and particularly if there is a persisting need to know blood gas tensions on a baby receiving more than $40 \%$ $\mathrm{O}_{2}$, catheters have been left in for considerably longer. The longest they have been left in place is 20 days, and several babies have exceeded 8 days without ill effect.

\section{Results}

In four years 381 attempts have been made to insert arterial catheters with 46 failures (12\%) (Table IV). However, as we became more skilful our failure rate dropped. Most cases of failed insertion were due to obstruction at one of the two

\section{TABLE IV}

Number of Catheterizations Attempted and their Outcome

\begin{tabular}{c|c|c|c|c}
\hline Year & $\begin{array}{c}\text { No. } \\
\text { Inserted }\end{array}$ & No. Failed & $\begin{array}{c}\text { No. Compli- } \\
\text { cations }\end{array}$ & Total \\
\hline 1963 & 38 & $11(22)$ & $4(10)$ & 49 \\
1964 & 94 & $18(16)$ & $10(11)$ & 112 \\
1965 & 73 & $4(5)$ & $7(10)$ & 77 \\
1966 & 130 & $13(9)$ & $13(10)$ & 143 \\
\hline & 335 & $46(12)$ & $34(10)$ & 381 \\
\hline
\end{tabular}

Percentages are given in parentheses.

* Calculated as a \% of successful catheterizations.

\section{TABLE V}

\section{Reasons for Inserting Umbilical Artery Catheter}

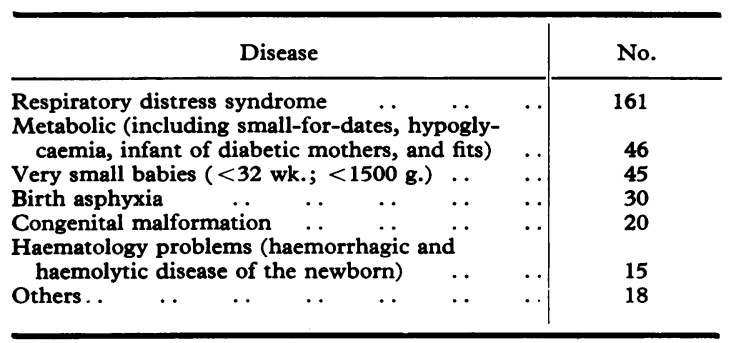

TABLE VI

Complications of Umbilical Arterial Catheterization

\begin{tabular}{|c|c|c|c|c|c|}
\hline \multicolumn{3}{|c|}{ Year } & Haemorrhage & $\begin{array}{c}\text { Clinical } \\
\text { Obstruction }\end{array}$ & $\begin{array}{c}\text { Thrombosis } \\
\text { at } \\
\text { Necropsy }\end{array}$ \\
\hline $\begin{array}{l}1963 \\
1964 \\
1965 \\
1966\end{array}$ & $\begin{array}{l}\cdots \\
\cdots \\
\cdots\end{array}$ & $\begin{array}{l}\cdots \\
\cdots \\
\cdots \\
\cdots\end{array}$ & $\begin{array}{l}4 \\
3 \\
1 \\
5\end{array}$ & $\begin{array}{l}-6 \\
5 \\
6\end{array}$ & $\begin{array}{l}- \\
1 \\
1 \\
3 *\end{array}$ \\
\hline Total & . & $\cdots$ & 13 & 17 & 5 \\
\hline
\end{tabular}

Total with arterial occlusion $=21$.

* Includes a baby who had clinical signs of thrombosis.

levels mentioned above, or to creating a false passage. It is interesting to note that our only 5 attempts to catheterize a single artery have all failed.

Arterial catheterization was carried out in babies who needed frequent blood sampling. This was particularly so in babies with respiratory illness (Table V). Other indications were infants of diabetic mothers, small-for-dates babies at risk from hypoglycaemia, and in haemolytic disease where they can be used as a route for exchange transfusion.

Complications occurred in $10 \%$ of catheterized cases, a figure that has remained remarkably constant (Table IV and VI). There were 13 cases of haemorrhage due to the arterial catheter: 3 cases involving the biggest bleeds occurred in the early part of the series, due in 2 cases to the catheter slipping out of the artery and in the other to the bung coming out of the catheter. Repetition of these accidents has been prevented by the measures described above. The other 10 bleeding episodes were of the order of 5-10 ml.; they occurred when removing the catheter and were due to inadequate haemostasis on pulling the purse-string suture tight. This again can be prevented by attention to the details of freshening the cord before removal. None of these 10 babies came to any harm.

Evidence of arterial obstruction occurred in 21 cases, an incidence of $6 \%$ (Table VI and VII). In 17 cases we had clinical evidence of arterial obstruction during life with one limb becoming blue or white with feeble pulses. Two children (Cases 6 and 10) were moribund and the legs went pale during the last hour of life, presumably as part of a failing circulation. In Case 6, a hypertonic contrast medium was being used for angiocardiography at the time the leg went pale. No action was taken and at necropsy no arterial lesion was seen. In the 15 other children the catheters were removed and in 10 the limb returned to normal colour at once. Of these 10 babies, 2 (Cases 1,4 ) subsequently 
TABLE VII

17 Cases Complicated by Arterial Obstruction

\begin{tabular}{|c|c|c|c|c|}
\hline Case No. & $\begin{array}{l}\text { Gestation } \\
\text { (wk.) }\end{array}$ & $\begin{array}{c}\text { Weight } \\
(\mathrm{g} .)\end{array}$ & $\begin{array}{l}\text { Duration of } \\
\text { Arterial Catheter } \\
\text { in Situ (hr.) }\end{array}$ & Outcome \\
\hline 1 & 25 & 760 & 24 & $\begin{array}{l}\text { Removed; leg circulation immediately restored; died; arteries intact at } \\
\text { necropsy }\end{array}$ \\
\hline 2 & 31 & 820 & 11 & Removed; leg circulation immediately restored; alive and well \\
\hline $\begin{array}{l}3 \\
4\end{array}$ & $\begin{array}{l}29 \\
24\end{array}$ & $\begin{array}{l}920 \\
980\end{array}$ & 5 & $\begin{array}{l}\text { Removed; leg circulation immediately restored; alive and well } \\
\text { Removed; leg circulation immediately restored; died; at necropsy arteries } \\
\text { intact }\end{array}$ \\
\hline $\begin{array}{l}5 \\
6\end{array}$ & $\begin{array}{l}28 \\
37\end{array}$ & $\begin{array}{l}1060 \\
1160\end{array}$ & $\begin{array}{c}2 \\
62 \frac{1}{2}\end{array}$ & $\begin{array}{l}\text { Removed; leg circulation immediately restored; alive and well } \\
\text { No action; died } 1 \mathrm{hr} \text {. later; at necropsy arteries intact; cyanotic heart } \\
\text { disease }\end{array}$ \\
\hline $\begin{array}{l}7 \\
8\end{array}$ & $\begin{array}{l}32 \\
27\end{array}$ & $\begin{array}{l}1270 \\
1340\end{array}$ & $\begin{array}{r}12 \\
8\end{array}$ & $\begin{array}{l}\text { Removed; leg circulation immediately restored; alive and well } \\
\text { Removed; no effect; other artery catheterized; died; arteries intact at } \\
\text { necropsy }\end{array}$ \\
\hline 9 & 29 & 1380 & 3 & $\begin{array}{l}\text { Left arm blue; leg no arterial disease; withdrawn } 1 \mathrm{~cm} \text {; circulation } \\
\text { immediately restored; alive and well }\end{array}$ \\
\hline 10 & 30 & 1440 & $7 \frac{1}{2}$ & $\begin{array}{l}\text { No action; died } 1 \mathrm{hr} \text {. later; at necropsy arteries intact; severe hyaline } \\
\text { membrane disease }\end{array}$ \\
\hline 11 & 40 & 1800 & 90 & Removed; leg circulation restored over $2-3 \mathrm{hr}$; ; alive and well \\
\hline 12 & 30 & 1800 & On insertion & Removed; leg circulation immediately restored ... \\
\hline 13 & 34 & 1930 & 10 & Removed; no effect; thrombosed aorta and right iliac arteries at necropsy \\
\hline 14 & 33 & 2040 & 2 & $\begin{array}{l}\text { Removed; leg circulation slowly improved; dry gangrene } 2 \text { nd toe; alive } \\
\text { and well (see text) }\end{array}$ \\
\hline $\begin{array}{l}15 \\
16\end{array}$ & $\begin{array}{l}36 \\
38\end{array}$ & $\begin{array}{l}2100 \\
2780\end{array}$ & $\begin{array}{c}4 \frac{1}{2} \\
\text { On insertion }\end{array}$ & $\begin{array}{l}\text { Removed; no effect; alive and ?well; no occlusion } \\
\text { Removed; leg circulation immediately restored; alive and well }\end{array}$ \\
\hline 17 & 40 & 3420 & $22 \frac{1}{2}$ & $\begin{array}{l}\text { Removed; leg circulation immediately restored; catheters inserted into } \\
\text { other artery; alive and well }\end{array}$ \\
\hline
\end{tabular}

died and the arterial tree was intact at necropsy. (In Case 9 the catheter was deliberately inserted a long way to try and sample preductal blood. Shortly after insertion the child's left arm became blue and pulseless presumably due to the catheter wedging in the subclavian artery. The catheter was withdrawn $1 \mathrm{~cm}$. and the colour and pulses returned.)

Of the 5 cases where the limb did not immediately improve in colour, 2 (Cases 8 and 17) had peripheral cyanosis of both legs, which was not improved by removing the catheter and was presumably not due to arterial obstruction. Case 8 subsequently died and the arterial tree was normal at necropsy. In Case 12, where the catheter was used for injecting a hypertonic glucose solution, one leg became blue and mottled and, on removal of the catheter, did not return to normal colour for several hours. She made a complete recovery without sequelae. In Case 14 the arterial catheter was used for exchange transfusion using ACD blood and on unswaddling the child at the end the left foot was white. The catheter was removed and the foot slowly improved in colour. The tip of the second toe developed dry gangrene and separated cleanly. The child is now over 1 year old, well, and with no evidence of arterial disease in the leg. Case 13 was the only one in which clinical evidence of an arterial thrombosis was confirmed at necropsy. Necropsies were carried out on 144 of the 148 babies who died and in whom umbilical artery catheters were passed: 5 (Table VIII) showed signs of thrombosis of the great vessels despite the fact that only one (Case 13) showed any clinical signs before death. In all cases the babies were gravely ill for 12 hours or more before death, and had signs of generalized peripheral circulatory failure. All were being artificially ventilated. In no case was the thrombosis the major cause of death. In 2 cases there was a mural thrombosis within the aorta. In 3 cases a branch of the abdominal aorta was occluded (Table VIII) with infarction of the organ supplied. Although these were not considered to be instrumental in the babies' deaths they were potentially serious complications. In Case 20, an injection of $50 \%$ glucose was given in the terminal stages for severe hypoglycaemia when no other route was available.

In almost all cases coming to necropsy with catheters in situ or removed, the umbilical artery which had been catheterized was thrombosed, but in only the 3 cases above was there any thrombosis of the iliac vessels. Haemorrhage into the wall of the umbilical artery catheterized, or the small thrombi at the junction of the umbilical and iliac arteries, described by Ainsworth et al. (1963), have not been encountered. In 2 recent cases we have seen a sheath of thrombus around the tip of the arterial catheter (Fig. 2), which was within the aorta at death, and in 2 other catheterized cases 
TABLE VIII

5 Cases Complicated by Arterial Thrombosis at Necropsy

\begin{tabular}{|c|c|c|c|c|c|c|}
\hline Case No. & $\begin{array}{l}\text { Gestation } \\
\text { (wk.) }\end{array}$ & Weight (g.) & $\begin{array}{l}\text { Duration of } \\
\text { Catheter in } \\
\text { Situ (hr.) }\end{array}$ & Vessel Occluded & Sequelae & Main Cause of Death \\
\hline 18 & 32 & 1000 & $41 \frac{1}{2}$ & Inferior mesenteric & $\begin{array}{l}\text { Infarction transverse } \\
\text { splenic and sigmoid } \\
\text { colon }\end{array}$ & $\begin{array}{l}\text { Hypoglycaemia, aspira- } \\
\text { tion }\end{array}$ \\
\hline 19 & 32 & 1490 & $31 \frac{1}{2}$ & $\begin{array}{l}2 \mathrm{~cm} \text {. mural on aorta; } \mathrm{rt} . \\
\text { common iliac art.; rt. } \\
\text { internal iliac art. }\end{array}$ & 一 & $\begin{array}{l}\text { Severe hyaline membrane } \\
\text { disease }\end{array}$ \\
\hline 20 & 32 & 1640 & 61 & Superior mesenteric & Infarcted small bowel & $\begin{array}{l}\text { Severe hyaline membrane } \\
\text { disease }\end{array}$ \\
\hline 13 & 34 & 1930 & 10 & $\begin{array}{l}2 \mathrm{~cm} . \text { aorta (mural); rt. } \\
\text { common iliac art.; rt. } \\
\text { internal iliac art. }\end{array}$ & White rt. leg & $\begin{array}{l}\text { Severe hyaline membrane } \\
\text { disease }\end{array}$ \\
\hline 21 & 38 & 3100 & 340 & $\begin{array}{l}\text { Both common iliac arts.; } \\
\text { rt. renal arts. }\end{array}$ & Infarcted rt. kidney & $\begin{array}{l}\text { Pseudomonas pyocyanea } \\
\text { septicaemia; hypergly- } \\
\text { cinaemia }\end{array}$ \\
\hline
\end{tabular}

there was an organized thrombus on the wall of the aorta at necropsy. All $\mathbf{4}$ had had the catheter in situ for longer than 4 days.

The arterial catheter was used for administering alkali and other drugs including antibiotics, anticonvulsants, 5-10\% glucose, THAM, $\mathrm{NaHCO}_{3}$, and calcium and magnesium salts without ill effect, though there would be no reason for preferring this route except as a matter of convenience. However, we would not recommend hypertonic solutions, particularly sugars. Analeptic drugs (nikethamide and nalorphine) should also be avoided as they may provoke thrombosis.

\section{Discussion}

Samples of arterial blood may be obtained from various sites for the determination of blood gas tensions in the newborn. Repeated arterial punctures are traumatic, dangerous, and inaccurate. We have found the most satisfactory method for obtaining arterial blood is to use umbilical arterial catheters. If this fails we recommend radial artery catheterization.

One danger of having easy access to blood samples is that too much may be taken. An accur- ate chart of how much is removed is kept, and not more than $10 \%$ of the babies' blood volume is removed (approximately $1 \%$ of its body weight). If this is exceeded, a transfusion of $15-20 \mathrm{ml}$. fresh heparinized compatible blood is given.

The theoretical complications of umbilical arterial catheterization are haemorrhage, infection, and vascular occlusion. Infection has not been a problem and routine swabs taken from the cord stump on removal of the catheter have been uniformly sterile. Blood cultures were not routinely done on babies who had umbilical arterial catheters inserted; the only babies whose blood was cultured, with positive results, were those with signs of overt infection elsewhere which was not obviously related to the catheterization procedure. Antibiotics were not used prophylactically and were only administered when indicated clinically for suspected or proven infection. Haemorrhage has occurred in $4 \%$ of our cases, but this can be avoided by scrupulous attention to detail. Arterial occlusion may be due to wedging of the catheter into a small artery or to thrombosis, and for this reason small babies seem particularly at risk, and in our series with obstruction, 12 out of 21 (57\%) occurred in

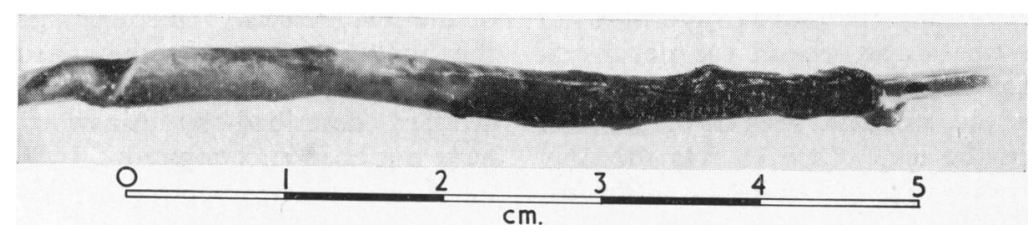

FIG. 2.-Catheter removed at necropsy showing a sheath of thrombus. 
babies under $1500 \mathrm{~g}$. If the colour of the limbs is carefully watched and the catheter removed at any sign of arterial occlusion, no serious sequelae result. However, only 1 of our 5 babies with arterial thrombosis revealed at necropsy showed any evidence of this during life. In only 1 baby, who lost the tip of her second toe, has there been any morbidity amongst survivors.

Arterial thrombosis is obviously a serious complication which has only occurred in gravely ill babies, where it was not the primary cause of death. Critically ill children are particularly prone to develop thromboses, and we have seen 5 newborn babies in the past 2 years with evidence of intraarterial thromboses at necropsy who either never had umbilical artery catheters inserted or who had signs of thrombosis before insertion of catheters. These infants were in peripheral circulatory failure, and in this state the presence of the foreign body in the form of the catheter may precipitate thrombosis. Further, as they are in circulatory collapse, pale, and cyanosed, colour changes in the limbs are difficult to detect. We accept as inevitable and of no consequence thrombosis in the umbilical arteries, and these are tied off peripherally and will have little, if any, blood in them. It appears advisable, however, to avoid giving hypertonic solutions, particularly dextrose, as 4 of our cases (Cases 6,12 , 14, and 20) were associated with administering them through the arterial catheter. In Case 14 one leg became white and pulseless during exchange transfusion with ACD blood, and recovery was slow. There are possible advantages in using the umbilical artery for both giving and extracting blood, rather than the umbilical vein, in an exchange transfusion. When the vein is used the catheter may slip through the ductus venosus, with the result that the blood is injected directly into the heart. Because of the risk of arterial spasm during injection the legs should be exposed for examination throughout the procedure and only fresh heparinized blood should be used.

The incidence of thrombotic casts of the arterial catheter and of mural thrombi of the aorta means that even babies without symptoms and signs of arterial obstruction in the neonatal period may sustain arterial injury to both the aorta and iliac vessels. As the babies with these lesions at necropsy were asymptomatic, we have no idea of its incidence in survivors. We know of no clinical evidence of arterial disease in babies' legs even in the baby who had the gangrenous toe. However, the follow-up of all these babies, which is now being undertaken, is incomplete.

In view of the $10 \%$ complication rate and the suspicion that aortic lesions may exist in survivors the procedure cannot be undertaken lightly. However, at present, there is no way of assessing the $\mathrm{P}_{\mathrm{a}} \mathrm{O}_{2}$ in premature babies receiving oxygen therapy other than measuring it directly on arterial blood. Arterial catheterization is thus justified for monitoring $\mathrm{P}_{\mathrm{a}} \mathrm{O}_{2}$, with the object of preventing hypoxaemia on the one hand and retrolental fibroplasia due to hyperoxaemia on the other; as also in babies where frequent blood sampling is necessary to detect the onset of metabolic illness such as hypoglycaemia.

\section{Summary}

The technique of umbilical artery catheterization is described. Complications occurred in $10 \%$ of a total of 335 insertions in the years 1963-66. 13 babies had haemorrhages none of which were serious. 17 showed clinical signs of arterial obstruction; in 16, these signs disappeared on removal of the catheter; 1 had arterial thrombosis at necropsy. In 4 other fatal cases arterial thrombosis was not detected before death. Only 1 survivor had any sequelae, and lost the tip of a toe.

Hypertonic solutions should not be injected through the catheters.

Umbilical artery catheterization is a simple and sometimes a necessary procedure, but not one without danger.

We wish to thank Professor J. P. M. Tizard for his help with the manuscript; Dr. A. E. Claireaux, the late Dr. M. J. R. Dawkins, and other members of the staff of the Morbid Anatomy Department of the Royal Postgraduate Medical School who carried out the post-mortem examinations; the resident neonatal medical officers; Sister M. S. Castle and nursing staff of the Neonatal Ward who looked after the babies during this period; and the Sir William Coxen Trust Fund for providing laboratory facilities.

\section{REFERENCES}

Ainsworth, R. W., Gairdner, D., Rack, J. H., and Webb, M. (1963). Umbilical artery for transfusion. Lancet, 1, 445.

Asnes, R. S., and Arendar, G. M. (1966). Septic arthritis of the hip: a complication of femoral venepuncture. Pediatrics, 38, 837.

Dahlenburg, G. W., Gupta, J. M., Roberton, N. R. C., and Tizard, J. P. M. (1968). The management of oxygen therapy in the newborn baby. In preparation.

Gupta, J. M., Dahlenburg, G. W., and Davis, J. A. (1967). Changes in blood gas tensions following administration of amine buffer THAM to infants with respiratory distress syndrome. Arch. Dis. Childh., 42, 416.

McKay, R. J., Jr. (1966). Risks of obtaining samples of venous blood in infants. Pediatrics, 38, 906.

Tizard, J. P. M. (1962). Portal hypertension following exchange transfusion through the umbilical vein. Proc. roy. Soc. Med., $55,772$.

Warley, M. A., and Gairdner, D. (1962). Respiratory distress syndrome of the newborn-principles in treatment. Arch. Dis. Childh., 37, 455. 